\title{
Estimates of stem wood increments in forest resources: comparison of different approaches in forest inventory: consequences for international reporting: case study of European forests
}

\author{
Andrius Kuliešis $^{1} \cdot$ Stein M. Tomter ${ }^{2} \cdot$ Claude Vidal $^{3} \cdot$ Adrian Lanz $^{4}$
}

Received: 30 December 2015 / Accepted: 12 May 2016 / Published online: 13 June 2016

(C) INRA and Springer-Verlag France 2016

\begin{abstract}
- Key message Quality and reliability of forest resource assessments depend on the ability of national forest inventories (NFIs) to supply necessary and high-quality data. Over the last decades and especially since the 1990s, the NFIs in European countries have been rapidly developing. Possibilities for obtaining reliable and accurate data on annual increment from different inventory types were evaluated, and sample-based inventories have been found to be superior to standwise inventories in providing reliable data. Simplified methods may be employed when increment cannot be directly estimated from inventory data. - Context An increasing intensity of forest resource use requires more accurate, detailed and reliable information, not
\end{abstract}

Handling Editor: Jean-Michel Leban

Contribution of the co-authors Andrius Kuliešis: coordination, ToS of SFM questionnaire design, data analysis and writing of manuscript

Stein Michael Tomter: ToS of SFM questionnaire design, data analysis and writing of manuscript

Claude Vidal: results analysis and writing of manuscript

Adrian Lanz: results analysis and writing of manuscript

Andrius Kuliešis

Andrius.Kuliesis@amvmt.lt; Ankulit@gmail.com

State Forest Service, Pramones av. 11A, 51327 Kaunas, Lithuania

2 Norwegian Institute of Bioeconomy Research, P.O. Box 115, N-1431 Ås, Norway

3 European Commission, Joint Research Centre, Institute for Environment and Sustainability, Forest Resources and Climate Unit, Via E. Fermi 2749, I-21027 Ispra (VA), Italy

4 Swiss Federal Research Institute WSL, Programme National Forest Inventory, Zürcherstrasse 111, CH-8903 Birmensdorf, Switzerland only on forest area and growing stock but also on forest stand productivity, wood increment and its components.

- Aims The main objectives were to assess the capacities of forest inventories, the methods used for estimation of gross increment and its components and their accuracy and to demonstrate an effective method for estimation of increment when direct inventory methods are not available.

- Methods Data about national forest inventory methods were obtained from 30 responses to a questionnaire, distributed amongst national correspondents of all European countries; reports of COST Actions E43 and FP 1001, databases of Temperate and Boreal Forest Resource Assessment (TBFRA) 2000 and State of Europe's Forests (SoEF) 2011 were used as well. Analysis and comparison of results from different forest inventories were used for evaluation of data reliability. Relationships between growing stock and gross increment in European forests were also analysed, and corresponding models were proposed.

- Results Seventy-nine percent of European forest area is covered by national forest inventories (NFIs) based on sampling methods and the rest on stand-level inventory and other inventory methods. Data obtained by aggregating standwise data usually underestimate growing stock by 15-20 \% and gross increment even more. Almost half of the European forest area $(47 \%)$ is monitored using permanent plots, measured twice or more, allowing the estimation of gross increment and its components to be made directly.

- Conclusion Implementation of NFIs based on sampling methods, especially with permanent plots, resulted in an improvement of data quality and in most cases an increase of growing stock and gross increment. The estimation of natural losses is the weakest link in today's NFIs and in the current assessment of European forest resources. The proposed default values for gross increment and its components is an option to be used in countries not having NFI at all or those which have started it only recently. 
Keywords Growing stock · Gross annual increment · Natural losses · Permanent plots · Inventory by sampling methods · Standwise inventory

\section{Introduction}

Increment plays a decisive role in the process of forest management control and estimation of its sustainability level. Since the increment quantities in comparison to the assessed volumes are relatively small and also subject to wide variation, exact increment evaluations are time-consuming and costly. Two basic terms are gross annual increment (GAI) and net annual increment (NAI). GAI is defined as the average annual volume of increment over the reference period of all trees measured to a minimum diameter at breast height of $0 \mathrm{~cm}$. NAI is GAI minus the volume of natural losses or trees that have died during the reference period. There exists a wide range of methods for estimation of increment. One method for assessing GAI would be to estimate annual increment for all individual trees (e.g. based on increment boring or diameter differences) and aggregate these for the entire assessment unit. In principle, the increment of trees that have died or have been felled during the period between measurements should also be added, although this quantity is often negligible. GAI can also be calculated from a number of other variables frequently included in forest resource assessments. These are the changes in growing stock, fellings and natural losses over an assessment period. Therefore, these quantities can be regarded as components of the GAI. NAI has been defined as GAI minus natural losses, alternatively as the change in growing stock plus fellings. These relationships are general and are described in textbooks as Loetsch et al. (1973).

European countries have developed very different inventory systems and different methods to assess gross increment and its components. Three main forest inventory methods can be distinguished at the country level in Europe:

- Inventory by sampling method, using permanent plots

- Inventory by sampling method, using temporary plots (a combination of permanent and temporary plots may also be used)

- Aggregation of data from standwise inventories

National forest inventories based on sampling method can also be integrated with GIS technology, allowing a direct estimation of the forest area to be made. In such a case, the total area of a certain stratum, region or country is the sampling frame. The area represented by one sample plot can be calculated by dividing the total area by the number of plots within the sampling frame or according to distance between equidistantly allocated plots. The forest area is then estimated by multiplying this value of area per sample plot by the number of sample plots in the forest.
The feasibility of national forest inventories for assessment of increment and related variables depends on which type of plots is used: permanent or temporary or both. After the installation and the first repeated measurement of plots, national forest inventories based on permanent sample plots are usually able to estimate directly and with known accuracy not only growing stock but also periodic gross increment and its main components. Such inventories have become reliable tools for assessment of forest resource dynamics, as well as control of forestry efficiency, the efficiency of forest logging and control of all other information related to wood flow from the forest.

National forest inventories based on temporary plots are capable of supplying reliable data with known accuracy on both growing stock and gross annual increment. Nevertheless, data on the various gross increment components, fellings and dead trees derived from temporary plots normally have lower accuracy. This lower accuracy is caused by a lack of direct measurement at tree level of increment and the greater difficulty of assessing the time of felling or death of trees, using only one single measurement of the sample plot. Several other aspects related to methods of increment estimation and their harmonization have been discussed by Gschwantner et al. (2016). Examples include sampling grid, use of remote sensing, sample tree selection methods, forest area changes, dbh thresholds, the use of models and tree parts included in estimates. All of these may to some extent influence the national increment estimates, although it is not always easy to say if one method is more correct than another.

Compilation of national inventory results by aggregating stand-level data for all forests has survived under conditions of a centrally planned economy (Brukas et al. 2002). Under other circumstances, it is problematic to ascertain the regularity and coverage of inventories independently of forest ownership. Data obtained from standwise inventories (SFI), especially those based on ocular estimates, are characterized by frequent systematic deviations. Gross increment, including its components, can only be estimated in an indirect way and is of low reliability. A complete coverage of stand-level inventory for a whole country normally takes $10-15$ years. During this period, forests change due to natural growth and silvicultural measures. The reasons for these changes are not recorded and cannot be accounted for. Many attributes important in forest assessments, such as gross annual increment and volume of felled, dead trees, cannot be reliably and cost-efficiently ascertained by applying stand-level inventory methods at all. National forest inventories (NFIs) based on permanent plots, on the other hand, is used to provide reliable estimates for most important attributes by a direct way and is also being used as a tool to validate all other inventories (Kuliešis et al. 2016).

The goals of this study were to assess the capacities of forest inventories and the methods used for estimating of gross increment and its components, to compare estimates of increment and its components obtained by different inventory methods 
and to demonstrate an effective method for estimation of increment when specific inventory data for estimation of increment are not available.

The main tasks of the study are the following:

1. To assess the capacities of European countries for estimating increment in forests;

2. To assess the impact of forest inventory methods on the quality of increment estimates;

3. To estimate relationships between various forest characteristics and gross annual increment including its components, to be used as an aid for future forest reporting in cases where extensive data are not available.

\section{Materials and methods}

Capacities for estimating increment have been evaluated by comparing European countries' reporting to international forest resource assessments in 2000 and 2011 and also by evaluating the main forest inventory methods in various countries that are employed as a basis for international forest reporting.

Three main sources of data were used for the study of gross increment and its assessment methods in Europe. Data about assessment methods were obtained from a questionnaire, distributed amongst national correspondents of all European countries, and UNECE/FAO Team of Specialists on Monitoring Sustainable Forest Management, as well as from country reports of COST Action E43 (Tomppo et al. 2010) and COST Action FP1001. Databases of Temperate and Boreal Forest Resource Assessment (TBFRA) 2000 (UNECE/FAO 2000) and State of Europe's Forests (SoEF) 2011 (FOREST EUROPE, UNECE and FAO 2011) were also used. Food and Agriculture Organization (FAO of the United Nations) has compiled data on forest resources for all countries in the world since 1948 . Since 2000, this reporting has been performed regularly every 5 years. FOREST EUROPE (formerly known as MCPFE), the Ministerial Conference on the Protection of Forests in Europe, normally convene their main conferences every $4-5$ years, and data are collected prior to these conferences for the preparation of an updated version of the report State of Europe's Forests.

Every country provides data on forest area and growing stock as a minimum for forest resource assessments (UNECE/FAO 2000; FOREST EUROPE, UNECE and FAO 2011; Tomppo et al. 2010). GAI is reported for the assessments by a more limited number of countries. The main reason is a lack of inventory methods able to supply such data. An analysis of gross annual increment and growing stock data showed that there is a correlation between these variables (Kuliešis 1993). It means that it is possible to use this relationship for estimating GAI from growing stock volume and other forest stand variables. All countries, according to the presented characteristics of growing stock for SoEF
2011, were classified into six groups (Fig. 1). The reporting comprised the reference years 1990, 2000, 2005 and 2010.

Complete data on gross increment for SoEF 2011 were presented by 12 countries only, however, not always for the entire 1990-2010 period. Only seven countries (Austria, Finland, Lithuania, Norway, Slovenia, Sweden and Switzerland) provided data on GAI and its components for SoEF 2011, estimated directly from measurements on permanent plots. Estimation of all components of gross increment, especially natural losses, is problematic for the rest of the countries. One possible solution is to assume a corresponding development in countries having similar growth conditions and silvicultural regimes. The relationship between growing stock and gross increment was investigated for groups of countries with similar growth conditions, grouped by classes of growing stock (FOREST EUROPE, UNECE and FAO 2011). All European countries were classified into six groups. A difference in mean growing stock of 40 $80 \mathrm{~m}^{3} /$ ha was used to identify the group. Countries not having NFI generally use various indirect methods for GAI estimation. Indirect methods usually give underestimated values of GAI, compared with direct or semi-direct methods of GAI estimation. That was the reason for splitting the second and third group of countries into two subgroups. Mean growing stock, gross increment, its components and their relationships were estimated for every country group using data from TBFRA 2000 and SoEF 2011. Data on thinnings and natural losses in forests of Lithuania, Sweden and Norway during 2010-2012 were also utilized. More complicated relations between components of gross increment in uneven-aged forest stands were assessed in forests of five different regions (Jura, Plateau, Pre-Alps, Alps, Southern Alps) of Switzerland during four time periods (19831985, 1993-1995, 2004-2006, 2009-2011).

The results of the analysis were used to evaluate possibilities for developing default values for gross increment and its components. Although default values for increment estimation will not provide estimates of the same quality as a detailed inventory, it would be beneficial if countries with a lack of data could be able to provide at least an approximate estimate, rather than no data at all.

\section{Results}

\subsection{Comparison between GAI, its components and growing stock reported to the forest resource assessments TBFRA 2000 and SoEF 2011}

\subsubsection{Participation of countries in international forest resource assessments}

Data on total forest area and growing stock were presented by all 43 European countries according to agreed formats and definitions. Countries' ability to respond to other questions differs 


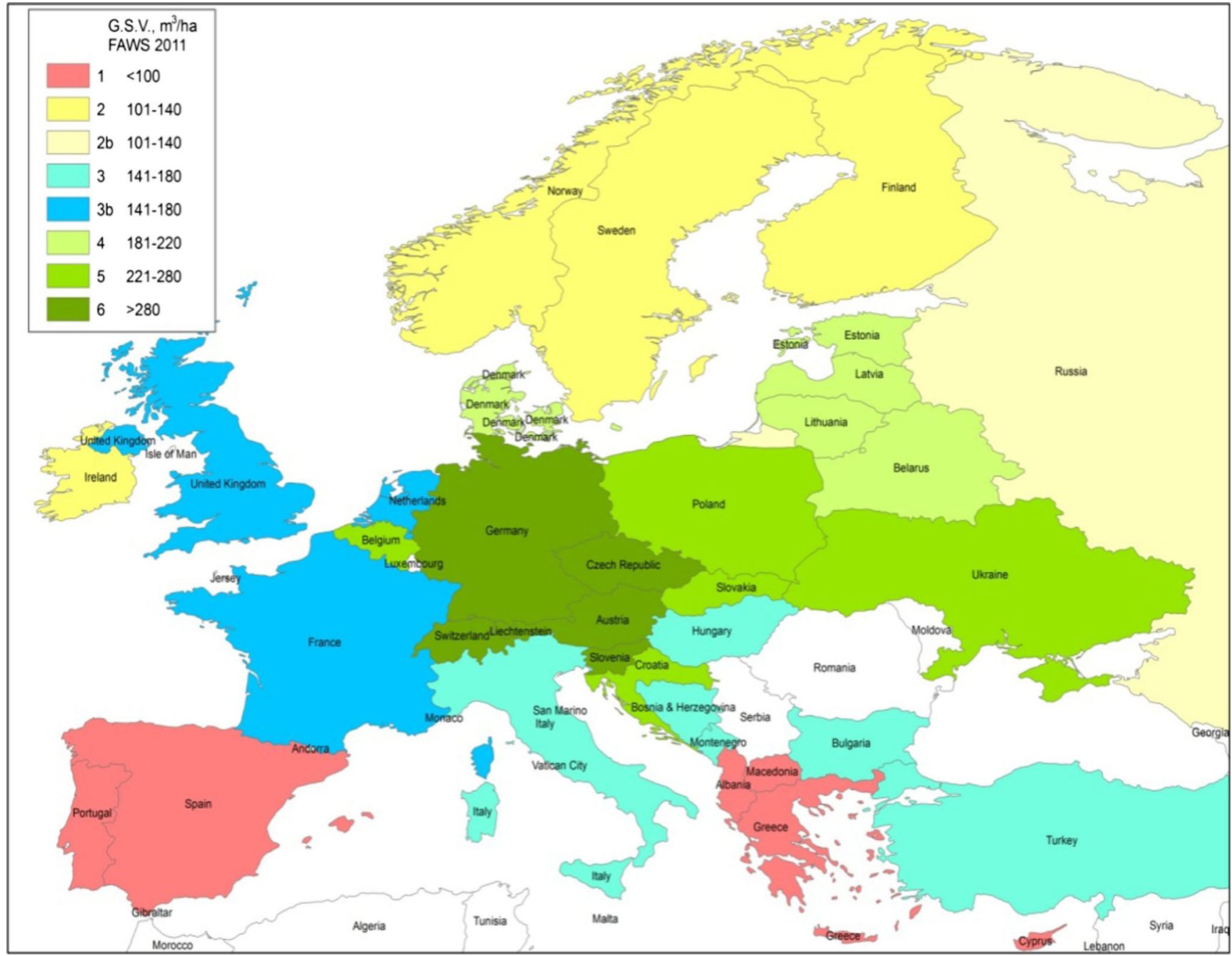

Fig. 1 European country groups by mean growing stock, SoEF 2011 (Albania, Cyprus, Greece, Macedonia, Portugal, Spain (1); Finland, Ireland, Norway, Sweden (2); Russian Federation (2b); BosniaHerzegovina, Bulgaria, Hungary, Italy, Montenegro, Turkey (3); France,

quite a lot, especially for those questions where more complex inventory methods are required. An analysis of countries' data reporting on GAI and its components shows a change in activity over the period between 2000 and 2011 (Fig. 2).

Most countries reported on fellings and net annual increment, which is one of the most important pan-European indicators for sustainable forest management. Countries use for their reporting not only data from inventories but also from industry and market statistics, i.e. from sources outside forest inventory. Countries were generally more active in TBFRA 2000 compared to SoEF 2011 in reporting all variables (Fig. 2). The number of countries reporting GAI and natural losses for 2011 decreased to the level of $44-58 \%$ analysed by considering the forest area and growing stock represented by the countries, compared to 92 $95 \%$ in the year 2000 (Fig. 2b, c). Reporting on fellings and net increment was more stable in both assessments and changed from $94-99 \%$ in 2000 to $83-92 \%$ in 2011 (Fig. 2b, c). The number of countries reporting fellings and net increment
Netherlands, UK ( $3 b$ ); Belarus, Denmark, Estonia, Latvia, Lithuania (4); Belgium, Croatia, Poland, Romania, Slovakia, Ukraine (5); Austria, Czech Republic, Germany, Liechtenstein, Slovenia, Switzerland (6))

decreased more noticeably, from $39-40$ in 2000 to $28-33$ in 2011 (Fig. 2a). Only a few European countries (Austria, the Netherlands, Norway, Sweden, Switzerland) had the possibility at the end of the twentieth century to present reliable data about all gross increment components based on direct measurements on permanent NFI plots. Nevertheless, some countries including Albania, Belarus, Bulgaria, Estonia, Hungary, Latvia, Lithuania, Moldova, Poland, Romania, Slovakia and Turkey presented data for TBFRA 2000 on gross and net increment, natural losses and fellings based on expert estimates, modelling and information on removals. Only some of the countries did specify this information 10-20 years later, using NFI data with one remeasurement as a minimum (Fig. 3). Countries are not legally required to report data to the process conducted by FOREST EUROPE, which may be one of the reasons for the incompleteness of the presented data. Countries with fewer forest resources usually also have smaller forest inventory capacities and fewer possibilities to present complete data. 




Fig. 2 Number of countries (a), area of FAWS (b) and growing stock (c) in European forests (excluding Russian Federation), for which gross annual increment and its components were reported in the 2000 and 2011 assessments

\subsubsection{European forest inventory methods and their changes}

An analysis of forest inventory methods, reported by respondents of questionnaires and materials presented in the book published under COST Action E43 (Tomppo et al. 2010), allows us to rank all countries according to their application of NFI by sampling method (Fig. 3), as well as to estimate what portions of forest area and growing stock are surveyed by various inventory methods in Europe (Table 1). The first national forest inventories by sampling methods were implemented by Norway (1919), Finland (1921) and Sweden (1923) (Tomppo et al. 2010). These inventories allowed an objective estimate of the main parameters of forest resources to be made, such as growing stock and gross increment. Inventories capable of supplying data on gross increment components, such as natural losses and fellings, were started in 1980 1986 by Austria, the Netherlands, Sweden, Switzerland, Norway, Germany and Spain (Tomppo et al. 2010). A pioneer in this field was the USA, which started continuous forest inventory on the basis of permanent plots in the 1930s (Stevenson and Meyer 1940; Stott and Ryan 1939). All European countries that started their NFI after 1997 (Lithuania, Estonia, Luxembourg, Slovenia, etc.; shown in Fig. 3) used permanent plots in their sampling designs from the beginning. France introduced "semi-permanent" plots in 2005, allowing repeated measurements for certain purposes, such

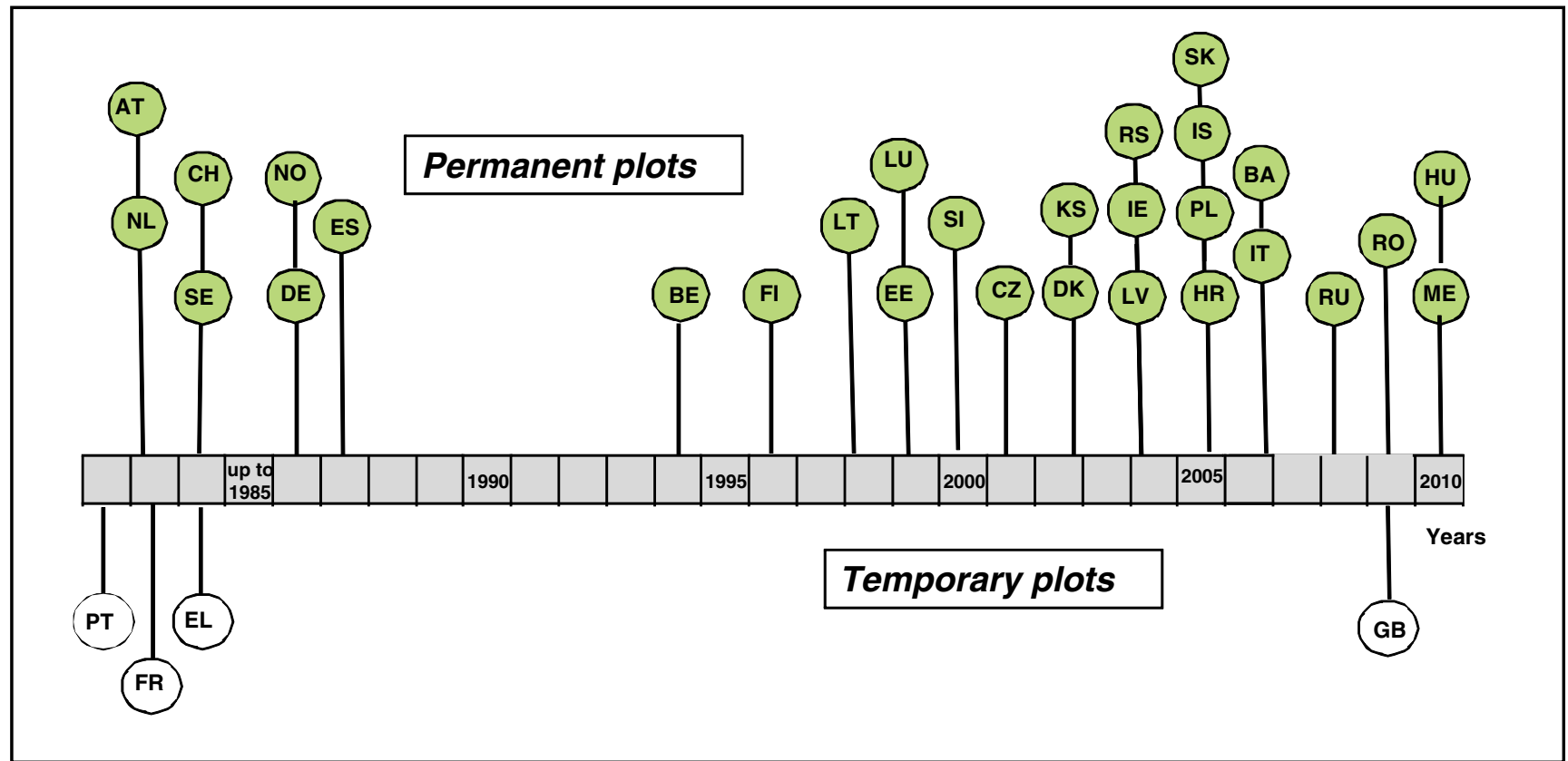

Fig. 3 Implementation of NFI based on sampling methods, in European forests (Austria $(A T)$, Bosnia-Herzegovina $(B A)$, Belgium $(B E)$, Switzerland $(\mathrm{CH})$, Czech Republic $(\mathrm{CZ})$, Germany (DE), Denmark $(\mathrm{DK})$, Estonia $(E E)$, Greece $(E L)$, Spain (ES), Finland $(F I)$, France $(F R)$, Great Britain $(G B)$, Croatia $(H R)$, Hungary $(H U)$, Ireland $(I E)$,
Iceland (IS), Italy (IT), Kosovo $(K S)$, Lithuania $(L T)$, Luxembourg $(L U)$, Latvia $(L V)$, Montenegro $(M E)$, Netherlands $(N L)$, Norway $(N O)$, Poland $(P L)$, Portugal $(P T)$, Romania $(R O)$, Serbia $(R S)$, Russia $(R U)$, Sweden $(S E)$, Slovenia $(S I)$, Slovakia $(S K))$ 
Table 1 Distribution of European forest area and growing stock by the main inventory methods

\begin{tabular}{llllll}
\hline Indicator & & NFI by sampling method & Stand-level inventory & Other methods & Total \\
\hline Forest area & $10^{6}$ ha & 172.2 & 34.0 & 4.7 & 210.9 \\
& $\%$ & 82 & 16 & 2 & 100 \\
Growing stock & $10^{9} \mathrm{~m}^{3}$ & 26.2 & 5.9 & 0.6 & 32.7 \\
& $\%$ & 80 & 18 & 2 & 100 \\
\hline
\end{tabular}

as assessment of major damage, and enlarged the scope of remeasurements in 2013 to make direct estimation of growing stock and increments. Most countries re-measure plots every 5 years, allowing reliable estimates of natural losses to be made. Countries using 10 years or longer re-measurement periods, especially in intensive growth zones, often have problems with identification of natural losses.

Up to now, 29 European countries, including the Russian Federation, have implemented NFI based on permanent plots and four countries based on temporary plots (Fig. 3). Completion of an NFI based on permanent plots takes from some years up to 20-30 years and plays a varying role in forest assessment, as well as in evaluation of forest management decisions.

The distribution of forest area and growing stock in Europe, assessed by the two main inventory methods, is shown in Table 1. The data of forest area and growing stock volume, shown in Tables 1 and 2, are taken from SoEF 2011 (FOREST EUROPE, UNECE and FAO 2011). NFIs, based on sampling methods, have been used for $82 \%$ of the total European forest area or $80 \%$ of the corresponding growing stock. For the rest of forest area (18\%) and growing stock (20\%), stand-level forest inventory or other inventory methods are used (Table 1). The number and level of detail of parameters for forest stands, obtained by SFI, is limited and very often based on an ocular inventory method. Estimations are made with unknown accuracy, and forest resources are usually underestimated. Estimates of increment and especially its components are available only with low reliability and accuracy.

Three time periods (Fig. 3) with two peaks in 1999 and 2005 can be distinguished for NFI establishment in Europe: Seven countries launched NFIs based on permanent plots up to and around 1985, while three countries started or continued inventories based on temporary plots. Between 1994 and
2002, nine countries launched NFIs based on permanent plots, and since 2004, 13 other countries have done the same. European NFIs based on sampling methods use permanent plots for $85 \%$ of the forest area and $87 \%$ of the growing stock (Table 2). The majority of countries use periods of 5 10 years for permanent plot re-measurement or temporary plot establishment. It means that 5-10 years after an NFI with permanent plots has been established, data on growing stock and gross increment can be provided, analogous to NFIs based on temporary plots. The first data on gross annual increment and its components, obtained in a direct way, can be provided after the first repeated measurement of permanent plots has been carried out.

That was the idea to divide all countries using NFI with permanent plots, into three groups: (1) countries (10) that have established NFIs with permanent plots up to 2000 and having at least two and more completed measurements; (2) countries (10) with established permanent plots from 1994 up to 2006, having at least one repeated measurement and (3) countries (8, excluding Russian Federation) with ongoing establishment or first repeated measurement of permanent plots (corresponding to Table 2).

\subsubsection{The impact of inventory methods on the quality of increment and growing stock assessments}

Some countries (Lithuania, Estonia, Denmark, Ireland, Latvia) have reported data for TBFRA 2000, based on SFI, while they used sampling-based NFI data for the same time period when reporting to SoEF 2011. Growing stock, assessed by SFI, is for these countries generally underestimated by 15-20\% and more (for example $30 \%$ in Ireland) compared with the later

Table 2 Distribution of European forest area and growing stock by types of national forest inventories, based on sampling methods

\begin{tabular}{|c|c|c|c|c|c|c|c|c|c|}
\hline \multirow[t]{2}{*}{ Indicator } & & \multicolumn{4}{|l|}{ Permanent plots } & \multicolumn{3}{|c|}{ Temporary plots } & \multirow[t]{2}{*}{ Total } \\
\hline & & $\begin{array}{l}\text { Re-measured } \\
\text { twice or more }\end{array}$ & $\begin{array}{l}\text { Re-measured } \\
\text { once }\end{array}$ & $\begin{array}{l}\text { Establishment } \\
\text { is ongoing }\end{array}$ & Total & $\begin{array}{l}\text { Established } \\
\text { up to } 1990\end{array}$ & $\begin{array}{l}\text { Establishment } \\
\text { is ongoing }\end{array}$ & Total & \\
\hline \multirow[t]{2}{*}{ Forest area } & $10^{6}$ ha & 100.0 & 18.7 & 27.3 & 146 & 23.3 & 2.9 & 26.2 & 172.2 \\
\hline & $\%$ & 58 & 11 & 16 & 85 & 13 & 2 & 15 & 100 \\
\hline \multirow[t]{2}{*}{ Growing stock } & $10^{9} \mathrm{~m}^{3}$ & 13.4 & 4.5 & 4.9 & 22.8 & 3.0 & 0.4 & 3.4 & 26.2 \\
\hline & $\%$ & 51 & 17 & 19 & 87 & 11 & 2 & 13 & 100 \\
\hline
\end{tabular}


assessment based on NFI data (Fig. 4). GAI, assessed by SFI, is underestimated even more (20-30\%), as a result of a lower growing stock estimate and inaccurate stand characteristics, according to which models or tables for GAI estimation are chosen. For every consecutive SFI, a less pronounced underestimation of the main stand characteristics is typical, as well as a smaller estimation bias, every time giving a smaller difference in growing stock compared with the real situation. This feature of standwise inventory is especially harmful to carbon assessment results, based on estimated changes in growing stock. Due to results that are actually becoming more accurate over time, the estimated amount of the accumulated biomass in forest stands can be highly overestimated.

Ireland estimated growing stock for the year 2000 at $110 \mathrm{~m}^{3} /$ ha, using NFI 2006 data, while it was estimated at $74 \mathrm{~m}^{3} / \mathrm{ha}$ according to FRA 2000, using SFI data (Fig. 4). According to NFI 2012 (Forest Service 2013), the current growing stock was estimated at $133 \mathrm{~m}^{3} /$ ha, while according to NFI 2006, estimate was $103 \mathrm{~m}^{3} /$ ha (Forest Service 2013).

NFI and regular SFI are performed in parallel all over the territory of Lithuania. A comparison of the main forest stand characteristics, estimated by the SFI and NFI over a period of 15 years (1998-2012), shows rather pronounced differences (Kuliešis et al. 2016). Growing stock of all stands in the SFI was underestimated up to $15 \%$. A follow-up of the analysis of the results from NFI and SFI, including methods, standards and models, indicates a positive development towards increased accuracy of the SFI at the country level. The underestimation of growing stock decreases gradually over the first 5year period compared with the last 5-year period, from 15 to $9 \%$ in all stands and from 17 to $12 \%$ in mature stands. This is a result of the application of objective inventory methods in the more valuable, mature stands in the SFI, as well as continuous training of surveyors of the SFI, in addition to harmonization of models and standards used in the SFI and NFI. Harmonizations of form factors (Kuliešis et al. 2012) and mean height estimation models (Kuliešis et al. 2014) used in the NFI and SFI resulted in a decrease in the difference in growing stock obtained by these inventories of 1 to $3 \%$ in general and of 5 to $10 \%$ in young stands. Gross increment was underestimated $22.5 \%$ compared with the NFI by the Lithuanian SFI for the first 5 years (1998-2002). After 10 years, deviations decreased up to $18.8 \%$ due to more careful specification of models and additional training of surveyors (Kuliešis et al. 2016).

An analysis of GAI characteristics in countries of different forest productivity confirmed our previous result on the impact of inventory method on the gross increment estimates (Figs. 1 and 5 ). GAI in forests of group $2 \mathrm{~b}$ (Russian Federation) has an increment less than forests of the first group by $1.3 \mathrm{~m}^{3} / \mathrm{ha}$ on average and $2.9 \mathrm{~m}^{3} /$ ha less than the second group. Estimates of growing stock and GAI in countries of the second group are based on longterm continuous NFI and are likely to be reliable and of high accuracy. Countries of the second group and the Russian Federation, having very similar values of growing stock, would also be expected to have similar values of GAI. GAI reported by the Russian Federation for SoEF 2010 is, however, less than half compared with that of the countries of the second group. Increment in the forests of the Russian Federation is underestimated due to the specific estimation method applied in the country.

Growing stocks of country groups 3 and $3 \mathrm{~b}$ are very close, but GAI in forests of $3 \mathrm{~b}$ is $1.8 \mathrm{~m}^{3} /$ ha higher compared with the increment of country group 3 . The most likely reason for the difference between country groups 3 and $3 b$ is the assessment method. Countries of group $3 \mathrm{~b}$ use NFI, based on permanent (the Netherlands) or temporary (France, UK) plots (see Figs. 1 and 3, Table 3), while most of the countries in group 3 use
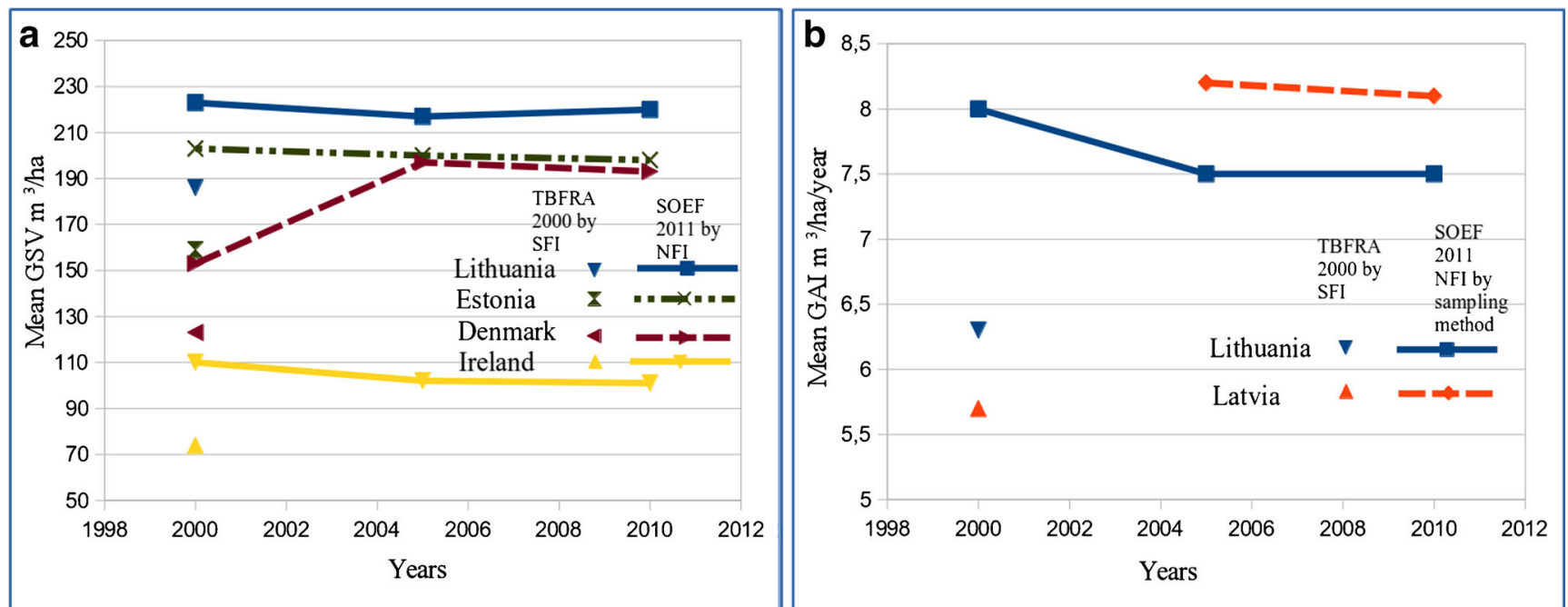

Fig. 4 Comparison of growing stock (a) and gross increment (b), using TBFRA-2000 data, based on standwise and SOEF-2011, based on national forest inventory by sampling method data 

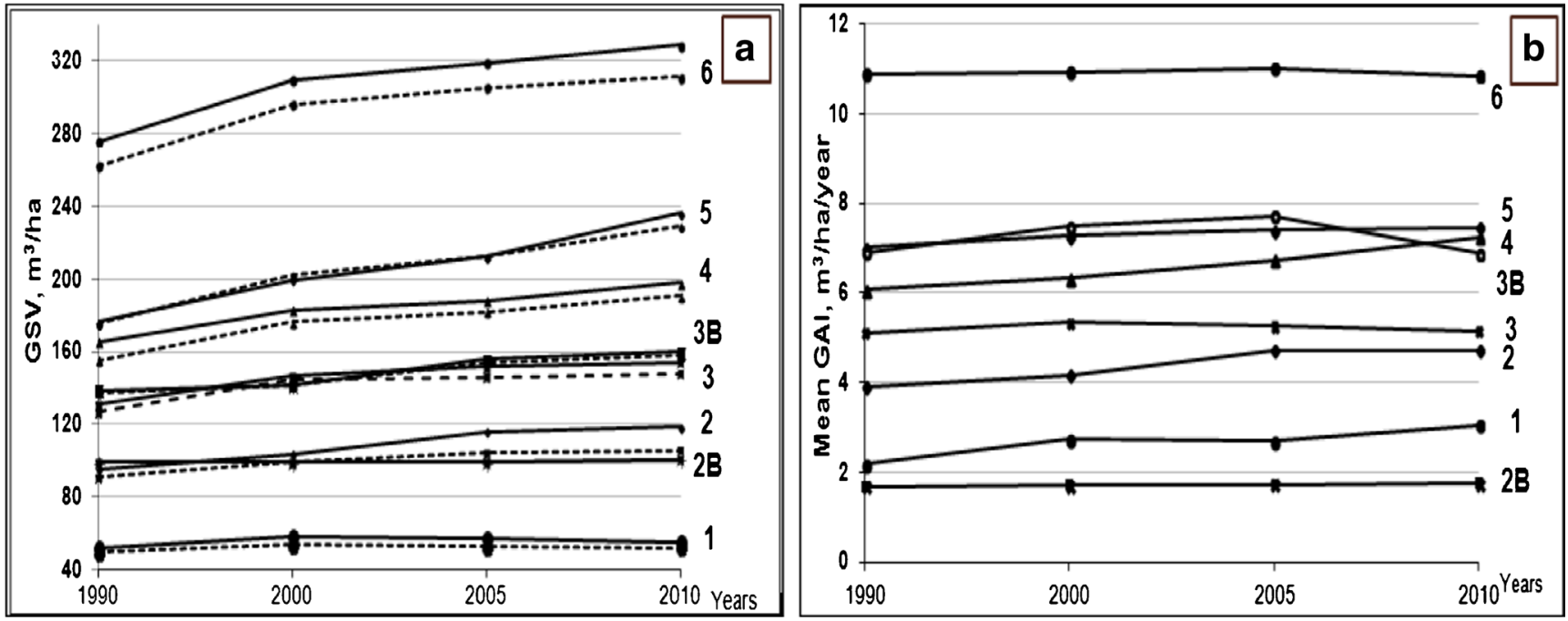

Fig. 5 Dynamics of growing stock volume (a) and gross annual increment (b) in FAWS and all European forests of different country groups, SoEF 2011 (FAWS (dashed line), all forests (solid line))

standwise forest inventories (Hungary, Bulgaria, Turkey). The NFI in some countries (Italy, Montenegro, Hungary) was launched less than 10 years ago, and more reliable results will be available for future assessments. For SFI, an underestimation of growing stock and GAI is characteristic (Fig. 4).

\subsection{Development of guidelines for simplified GAI assessment}

\subsubsection{The range of productivity of European forests}

All European countries were classified into six groups, according to their main indicator of productivity, expressed as mean growing stock (Fig. 1). For every group of countries with different forest productivity, a mean growing stock was estimated for all forests, for FAWS, as well as the mean age of stands and gross increment in stands. FAWS forests available for wood supply, where any legal, economic or specific environmental restrictions do not have a significant impact on the supply of wood (UNECE/FAO 2000). Growing stock in all European forests changes from $52 \mathrm{~m}^{3} /$ ha in the countries with the least forest productivity (first group) up to $311 \mathrm{~m}^{3} / \mathrm{ha}$ in forests of very high productivity (sixth group). Growing stock in FAWS is $4-17 \mathrm{~m}^{3} /$ ha higher compared with growing stock of all forests (Table 3).

The difference in growing stock between neighbouring groups of countries is on average $40 \mathrm{~m}^{3} / \mathrm{ha}$, as was accepted during grouping of countries, while it is $60 \mathrm{~m}^{3} /$ ha between the first and second group and $80 \mathrm{~m}^{3} /$ ha between fifth and sixth group. It is a tendency of growing stock to increase over time between 1990 and 2010, especially in country groups with forests of high productivity (Fig. 5).

Growing stock has been increasing at the order of $30 \mathrm{~m}^{3} / \mathrm{ha}$ in forests of the second group, up to $55 \mathrm{~m}^{3} / \mathrm{ha}$ in forests of the sixth group. Some countries have changed their inventory methods during this period. Usually, the forest inventory

Table 3 The mean characteristics of European forests by country groups ${ }^{\mathrm{a}}$ and productivity, SoEF-2011

Country group Forest productivity Total forest area Mean growing stock volume, $\mathrm{m}^{3} / \mathrm{ha}$ Mean age, years Mean gross annual increment in FAWS

\begin{tabular}{|c|c|c|c|c|c|c|c|c|}
\hline & & & & & \\
\hline & & Mill. ha & $\%^{\mathrm{b}}$ & Total & FAWS & & $\mathrm{m}^{3} / \mathrm{ha}$ & $\%$ \\
\hline 1 & Very low & 27.5 & 13 & 52 & 56 & n.a. & 3.1 & 5.5 \\
\hline 2 & Low & 61.7 & 29 & 106 & 118 & 58 & 4.7 & 4.0 \\
\hline $2 b$ & Low & 809.1 & & 101 & 101 & 72 & 1.8 & 1.7 \\
\hline 3 & Medium & 29.4 & 14 & 148 & 154 & 42 & 5.2 & 3.3 \\
\hline $3 b$ & Medium & 19.2 & 9 & 158 & 160 & 58 & 7.0 & 4.4 \\
\hline 4 & Intermediate & 16.9 & 8 & 191 & 198 & 48 & 7.2 & 3.7 \\
\hline 5 & High & 30.1 & 14 & 229 & 236 & 55 & 7.5 & 3.2 \\
\hline 6 & Very high & 20.1 & 10 & 311 & 328 & 61 & 10.3 & 3.1 \\
\hline
\end{tabular}

${ }^{\text {a }}$ Country groups in Fig. 1

${ }^{\mathrm{b}} \%$ excluding $2 \mathrm{~b}$ (Russian Federation) 
method was changed from SFI into a more reliable NFI by using sampling methods. The apparent increasing growing stock during 1990-2010 is a result not only of increased wood accumulation in forest stands due to growth but also to some extent due to different inventory methods (Fig. 4). An indirect method for estimating GAI is usually the only option for countries without an NFI. Such methods normally underestimate the increment compared with estimations by direct or semi-direct methods. That was confirmed by analysis of results of the second and third group of countries split into two subgroups.

GAI of different country groups changes in a similar way to growing stock (Fig. 5). GAI of the sixth country group exceeds the increment of the first country group on the average by $8 \mathrm{~m}^{3} / \mathrm{ha}$. The GAI differences between country groups are not as pronounced as the differences in growing stock. They depend on the variation of methods used by countries, not only for growing stock but also for increment estimation. Increment percentages during 1990-2010 period are in most cases stable, with a moderate increase (for countries of low forest productivity) or even decrease (for countries of higher forest productivity).

\subsubsection{Relationship between growing stock, gross mean annual increment and age}

Regression analysis of GAI, growing stock and mean age data, reported for SOEF 2011 by 17 countries, showed that the percentage of GAI can be expressed by Eq. (1), shown in Fig. 6. This relationship is suggested for deriving GAI in cases where this quantity is not directly available from existing forest inventory data

$\widehat{P}_{\mathrm{GAI}}=4.585-0.0042 M+0.010(50-A)(1) R^{2}=0.177$,

where $M$ is the mean growing stock volume, $\mathrm{m}^{3} / \mathrm{ha}$, and $A$ is the mean age, years (Fig. 6).

Deviations of gross annual increment did not exceed $15 \%$, calculated by Eq. (1) from data presented by 10 countries for
SoEF 2011, representing 85.1 million ha or $75 \%$ of the forest area of all 17 countries. Larger deviations are usually typical for countries not having long-term national forest inventories based on permanent plots (Croatia, Hungary, Italy, Turkey, UK).

\subsubsection{Approaches of natural loss estimation}

The most complete information of all components of GAI is data on volume of felled trees. Most problematic for countries is data on mortality or stem volume of dead trees. Data presented in TBFRA 2000 show that the share of natural losses of GAI in European forests varies from 2 to $7 \%$ (Austria, Finland, Norway, Sweden) up to 27-33\% (Belarus, Russian Federation). Observations on permanent plots, studies of several growth models and yield tables elaborated for even-aged stands (Kuliešis 1989, 1993; Pretzsch 2010; Kuliešis et al. 2010b) show that on average, 50-70\% of all increment can be accumulated and used by final felling, depending on forest stand growing conditions. The remaining part of gross increment (30-50\%) represents mortality or natural losses. Natural losses can be reduced by thinning. An increased number of thinnings and increased intensity of thinnings contribute to a reduction of the volume of dead trees and the natural losses. Utilization of dead trees also depends on the intensity of thinning. With increasing intensity of thinnings, the probability of using dead trees increases (Table 4). These conclusions were confirmed by analysing data of thinnings and natural losses in forests of Lithuania, Sweden and Norway. They allow to propose default values based on a theoretical approach of forest stand development (Tomter et al. 2016) for estimation of mortality (Table 4).

More complicated relations between components of GAI exist in uneven-aged forest stands. Study of gross increment components in forests of five different regions (Jura, Plateau, Pre-Alps, Alps, Southern Alps) of Switzerland during four periods (1983-1985, 1993-1995, 2004-2006, 2009-2011) showed a large variation in the components of GAI. All regions were divided into two parts according to the intensity of
Fig. 6 Mean gross annual increment percentage depending on mean growing stock volume (M) and age (A)

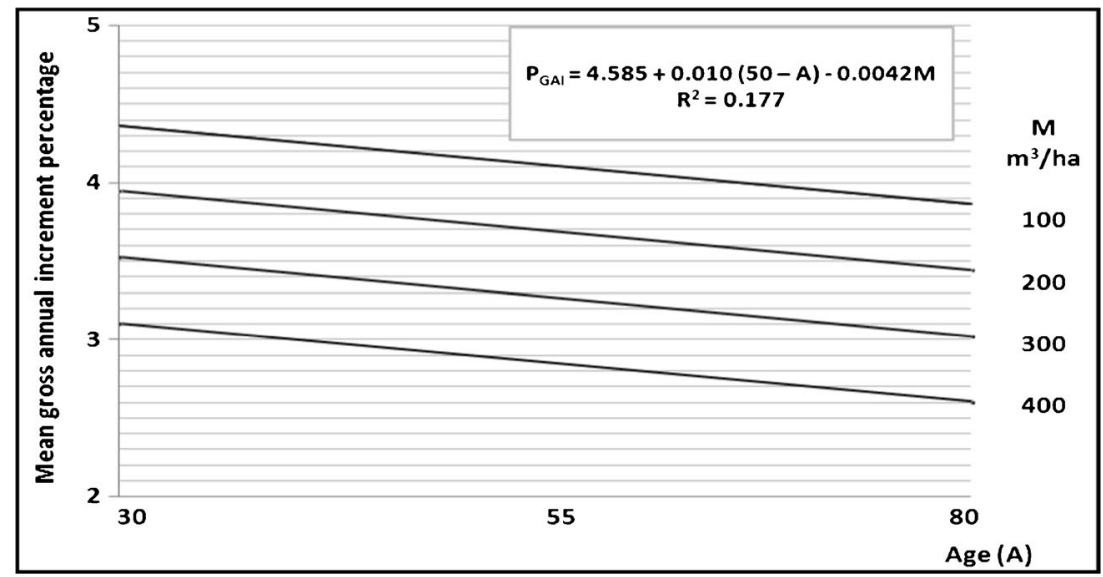

INRA פsprimes 
Table 4 Default values of natural loss percentage of gross increment $\left(P_{\mathrm{M} 0}\right)$ and volume percentage of felled dead trees $\left(P_{\mathrm{M} 0 \mathrm{~K}}\right)$ of total natural losses in even-aged stands depending on intensity of thinnings

\begin{tabular}{|c|c|c|c|c|}
\hline $\begin{array}{l}\text { Average intensity } \\
\text { of thinning, } \% \text { of } \\
\text { growing stock }\end{array}$ & $\begin{array}{l}\text { Average number of } \\
\text { commercial } \\
\text { thinnings per } \\
\text { rotation }\end{array}$ & $\begin{array}{l}\text { Share of wood } \\
\text { obtained from } \\
\text { thinnings in total } \\
\text { wood harvest }\end{array}$ & $\begin{array}{l}\text { Share of natural } \\
\text { losses in gross } \\
\text { increment, } \% \\
P_{\mathrm{M} 0}\end{array}$ & $\begin{array}{l}\text { Share of felled dead } \\
\text { trees in total natural } \\
\text { losses, } \% P_{\mathrm{M} 0 \mathrm{~K}}\end{array}$ \\
\hline \multirow[t]{6}{*}{$\leq 20$} & \multirow[t]{2}{*}{ Irregular } & \multirow[t]{2}{*}{$\leq 5$} & \multirow[t]{2}{*}{$\geq 26$} & 10 \\
\hline & & & & $50^{\mathrm{a}}$ \\
\hline & \multirow[t]{2}{*}{1} & \multirow[t]{2}{*}{$6-15$} & \multirow[t]{2}{*}{$21-25$} & 20 \\
\hline & & & & $60^{\mathrm{a}}$ \\
\hline & \multirow[t]{2}{*}{2} & \multirow[t]{2}{*}{$16-25$} & \multirow[t]{2}{*}{$16-20$} & 30 \\
\hline & & & & $70^{\mathrm{a}}$ \\
\hline \multirow[t]{4}{*}{$>20$} & \multirow[t]{2}{*}{2} & \multirow[t]{2}{*}{$26-35$} & \multirow[t]{2}{*}{$11-15$} & 40 \\
\hline & & & & $80^{\mathrm{a}}$ \\
\hline & \multirow[t]{2}{*}{3 and $>$} & \multirow[t]{2}{*}{$\geq 36$} & \multirow[t]{2}{*}{$\leq 10$} & 50 \\
\hline & & & & $90^{\mathrm{a}}$ \\
\hline
\end{tabular}

${ }^{a}$ Forests that have been damaged by heavy storms, invasion of insects or other agents during reference period fellings. Forests with a percentage of fellings of up to $50 \%$ of gross increment were assigned to the group of low intensity and over $50 \%$ to the group of high intensity. For forests of the first group, a high share of the dead tree volume of gross increment is characteristic (13-42\%) and correspondingly a low share $(2-25 \%)$ of felled dead tree volume of the total volume of dead trees. The intensity of fellings ranges from 34 to $106 \%$ of GAI in forests of the high-intensity group. Percentages based on this study were proposed as default values uneven-aged stands (Table 5).

Results from this study (Fig. 6, Tables 4 and 5) were included in technical documents of the Questionnaire on PanEuropean Indicators for Sustainable Forest Management 2015 , as an alternative for countries not having the possibility of estimating these variables in a direct way.

\section{Discussion}

The response rate from European countries for annual increment, fellings and natural losses was generally higher for the international forest resource assessment TBFRA 2000 than for

Table 5 Default values of natural losses $\left(P_{\mathrm{M} 0}\right)$ and percentage of felled dead trees $\left(P_{\mathrm{MOK}}\right)$ of total natural losses in uneven-aged stands depending on intensity of fellings

\begin{tabular}{lll}
\hline $\begin{array}{l}\text { Mean annual felling as a } \\
\text { percentage of gross } \\
\text { increment during reference } \\
\text { period, } \%\end{array}$ & $\begin{array}{l}\text { Share of natural } \\
\text { losses in gross } \\
\text { increment, } \% P_{\mathrm{M} 0}\end{array}$ & $\begin{array}{l}\text { Share of felled dead } \\
\text { trees in total natural } \\
\text { losses, } \% P_{\mathrm{M} 0 \mathrm{~K}}\end{array}$ \\
\hline $\begin{array}{l}\text { Up to } 50 \%(10-47) \\
51 \% \text { and more (34-106) }\end{array}$ & $14(13-42)$ & $5(2-25)$ \\
\hline
\end{tabular}

SoEF 2011. As inventory methods have been improving over this period, that is somewhat surprising. However, countries are not legally required to respond to these assessments, and the less number of responses may also be related to the workload on national correspondents, in that reporting has become more frequent and more comprehensive.

The reliability of assessments on forest resources depends mainly on the forest inventory data. For stand-level forest inventories not using sampling methods, an underestimation of the main stand parameters is typical (Kangas et al. 2004; Šmelko et al. 2008; Kuliešis et al. 2010a). The number of countries using NFI based on sampling methods in Europe increased from 10 at the beginning of the period (1990) up to 33 at the end of the period (2010). An especially big achievement of this period is the introduction of an NFI in the Russian Federation. Twenty-two countries launched NFIs based on permanent sample plots from 1999 and later. Some countries (Denmark, Estonia, Latvia and Lithuania) presented data from different sources for TBFRA 2000 and SoEF 2011. A comparison of data presented for the same year from different inventories shows that data on growing stock based on SFI are underestimated by 10-20\% (Fig. 4a). These differences are confirmed by NFI data from other countries. In the Czech Republic, the growing stock was estimated at $328 \mathrm{~m}^{3} /$ ha in the 2001-2004 NFI, compared with $280 \mathrm{~m}^{3} /$ ha according to SFI data for the same time (ÚHÚL 2007).

Another example is taken from Montenegro. Montenegro did not appear as an independent country in 2000 and did not report to TBFRA 2000. However, they carried out their first NFI in 2010 and had thus the possibility to compare the new data with previous estimates based on SFI. The previous estimate of GAI was $2.25 \mathrm{~m}^{3} /$ ha, while the new estimation according to the NFI was $3.5 \mathrm{~m}^{3} / \mathrm{ha}$ (Montenegro Ministry of Agriculture and Rural 
Development 2008, 2013). Since the forest area has also been found to be considerably larger by the NFI, it means that the total GAI is about twice as large as previously estimated.

In Poland, the difference between growing stock estimated by NFI 2012 and SFI of the same time was $6 \%$ (Talarczyk 2014). The rather low level of differences between growing stock data from the NFI and SFI in Poland can be explained by similar sampling designs (in both cases, statistically allocated plots were used) and similar principles in estimating growing stock in the SFI and NFI of Poland (Talarczyk 2014). In both cases, the estimates were based on individual trees.

NFIs based on permanent plots cover $69 \%$ and those based on temporary plots additionally $13 \%$ of the total European forest area, corresponding to a total growing stock of 70 and $10 \%$, respectively. Regular measurements of permanent plots are a source of reliable information on growing stock, its changes, gross increment and its components and especially the essential information on fellings and natural losses. The reliability of statistics will be improved over the next 10-20 years, when remeasurement of permanent plots will be completed in five countries, including the Russian Federation. The results of this study, as well as those from other authors (Kangas et al. 2004; Haara and Leskinen 2009; Šmelko et al. 2008; Kuliešis et al. 2010a), show that amongst the reasons for differences in growing stock are (1) applied models, (2) not updated data and (3) subjectivity of applied methods inventory.

Errors in the growing stock estimates will also seriously affect the estimates of GAI and its components (change in growing stock, fellings and natural losses). Models elaborated for the estimation of stem volume (including heights of individual trees based on a specific tree distribution by size) decrease mean height and mean growing stock up to $15 \%$, and on average up to 3-5\%, when they are applied for the estimation of mean characteristics of stands (Kuliešis et al. 2012). This is especially pronounced in young stands.

An analysis indicates a general increase of the growing stock, when data of different points in time are compared. For Europe, the change in growing stock represents on average $20-30 \%$ of gross increment (Tomter et al. 2016).

The subjectivity of surveyors can usually be estimated by comparing the results of subjective inventories with results of objective ones, performed at the same time and after excluding all other factors (different models, units of estimation, etc.). The results from an analysis of inventory methods and possible deviations of growing stock due to application of subjective methods indicate that the actual growing stock in European forests is likely to be higher than estimated for SoEF 2011.
Implementation of NFIs based on sampling methods resulted in an improvement of data quality and in most cases an increase of the reported growing stock and GAI. The impact is somewhat slower for gross increment than for growing stock. Reliable estimates of gross increment and its components are normally available only after the first or the second repeated measurement. In cases where re-measurements are done less frequently, such as every 10 or 15 years (Federal Ministry of Food, Agriculture and Consumer Protection 2006), difficulties arise in how to identify felled and dead trees.

Estimation of natural losses is the weakest link in today's NFIs and the current assessment of European forest resources. For SoEF 2011, data on gross increment were presented by 21 countries, and data on net increment by 28 countries. It means that in principle, 21 countries had the possibility to estimate natural losses. In reality, data on natural losses were reported only by 13 countries for SoEF 2011, and of these, only 9 countries had an NFI based on permanent plots. The natural losses reported for SoEF 2011, as a percentage of GAI, changes from 4.6 to $9.0 \%$ (Finland, Norway, Slovenia, Sweden) up to more than $17 \%$ (Austria, Lithuania, Switzerland). There is a reason to assume that due to practical management and the necessity to maintain and to enhance biodiversity, natural losses cannot be kept less than $5 \%$ or perhaps $10 \%$ of gross increment. The current natural losses significantly exceed this threshold in some countries. This fact also shows the necessity for applying more modern inventory methods and modern methodology, making it possible to assess gross increment and its components.

Studies have previously revealed a correlation between growing stock and GAI (Kuliešis 1989, 1993; Pretzsch 2010). The study of relationships between growing stock, age and gross increment make it possible to propose default values for gross annual increment and its components, as an option to be used in countries not having NFI at all or those which have started it only recently. Precision of predictions is often given as a percentage of mean observed value. In our case, the precision of predicted gross increment was estimated at $15 \%$ for $59 \%$ of all compared countries or $75 \%$ of their forest areas. The obtained precision is not very high but corresponds to the quality of the material used for the model (1), characterized by a high variation of data and a limited number of variables. Especially problematic for several countries is data on mortality or stem volume of dead trees. The likely intervals of this quantity, given as percentages of GAI, have been presented separately for even-aged and uneven-aged forest. Together with knowledge about forest management and the general forest situation of the country in question, these guidelines may be used to provide more complete reports to international forest resource assessments. 


\section{Conclusions}

1. European NFIs, organized on the basis of permanent plots by 29 countries and on temporary plots by four countries, represent a network of national forest inventories, supplying the community with a regular flow of information on the development of European forests.

2. Forest inventories, based on standwise surveys usually underestimate growing stock up to $10-15 \%$ and gross increment up to $15-20 \%$ compared with estimates obtained by inventories based on tree-level measurements. The main reasons for differences in growing stock, estimated during tree-level and stand-level inventories, are the same models, applied for estimation of the same parameters in stand (SFI) and tree (NFI) level inventories, ignoring the distribution of trees by their diameter or height in the stand; the lack of appropriate updating of SFI data; use of subjective methods by surveyors, which decreases rather than increases the value and accuracy of the characteristic.

3. Application of indirect methods for increment estimation during stand-level inventories is an additional source for decreasing gross increment accuracy, compared with that of corresponding growing stock estimates.

4. Natural losses represent the difference between gross and net increment and is a very important indicator of forestry efficiency. However, estimation of natural losses is the weakest link in today's NFIs and the current assessment of European forest resources. Only $43 \%$ of all countries, having the possibility to estimate natural losses, reported data for SoEF 2011.

5. The proposed default values for mean gross annual increment and its components, based on growing stock and age in addition to some theoretical approaches, is an option to be used in countries not having NFI at all or those which have started it only recently.

Acknowledgments This study has been developed in the framework of the Action COST FP1001 (USEWOOD: Improving Data and Information on the Potential Supply of Wood Resources: A European Approach from Multisource National Forest Inventories). We warmly thank all the members of Working Group 1 "Assessment and estimation techniques of state and changes in wood resources" for valuable discussions during the meetings, national correspondents for answering the Questionnaire on PanEuropean Indicators for Sustainable Forest Management and giving valuable information on development of national forest inventory capacities in their countries and R. Michalak from Forestry and Timber Section of UN Economic Commission for Europe for supporting the idea of distributing a questionnaire amongst the national correspondents. We thank very much Tracy Durrant Houston from the Forest Resources and Climate Unit at the JRC for her English review and improvement as well as anonymous reviewers for their constructive criticism.

\section{Compliance with ethical standards}

Funding This research was supported by the Cost Action FP1001: Improving Data and Information on the Potential Supply of Wood Resources: A European Approach from Multisource National Forest Inventories (USEWOOD).

\section{References}

Brukas A, Jakubonis S, Kuliešis A, Rutkauskas A (2002) Lietuvos miškotvarka ir jos raida (Forest management planning and its development in Lithuania.). Kaunas, Naujasis lankas, $188 \mathrm{p}$

Federal Ministry of Food, Agriculture and Consumer Protection (2006) The Second National Forest Inventory - NFI2. Results. Covering the National Forest Inventory Surveys of $2001-2002$ and $1986-$ 1988. Bundesministerium für Ernährung, Landwirtschaft und Verbraucherschutz (BMELV), Bonn

FOREST EUROPE, UNECE and FAO (2011) State of Europe's Forests 2011. Status \& Trends in Sustainable Forest Management in Europe. United Nations, Economic Commission for Europe, 337 p

Forest Service. Department of Agriculture, Food and the Marine (2013) The second national forest inventory - Republic of Ireland - Results. Covering the National Forest Inventory, 2009 to 2012. Department of Agriculture, Food and the Marine

Gschwantner T, Lanz A, Vidal C, Bosela M, Di Cosmo L, Fridman J, Gasparini P, Kuliešis A, Tomter SM, Schadauer K (2016) Comparison of methods used in European National Forest Inventories for the estimation of volume increment: towards harmonisation. Ann For Sci. doi:10.1007/s13595-016-0554-5

Haara A, Leskinen P (2009) The assessment of the uncertainty of updated stand-level inventory data. Silva Fennica 43:87-112. doi:10.142/4/ Sf. 219

Kangas A, Kangas J, Heikkinen E, Maltamo M (2004) Accuracy of partially visually assessed stand characteristics: a case study of Finnish forest inventory by compartments. Can J For Res 34:916930. doi:10.1139/x03-266

Kuliešis A (1989) Medynų našumas ir jo panaudojimas (Forest stand yield and use). Agroleidykla, Vilnius, $141 \mathrm{p}$

Kuliešis A (1993) Lietuvos medynu prieaugio ir jo panaudojimo normatyvai (Forest yield models and tables in Lithuania). Girios Aidas, Kaunas, p 384

Kuliešis A, Kulbokas G, Kasperavičius A, Kuliešis AA (2010a) Miškų inventorizacijos sistema ir jos tobulinimas pagal intensyvios miškininkystes reikmes (Forest inventory system and its development according to demands of high intensity forestry). Miškininkystė 2:61-77

Kuliešis A, Saladis J, Kuliešis AA (2010b) Development and productivity of young Scotch pine stands by regulating density. Balt For 16: 235-246

Kuliešis A, Kulbokas G, Kuliešis AA (2012) Medynų tūrio įvertinimo normatyvu harmonizavimas (The harmonization of growing stock volume estimation standards). Miškininkyste 1:7-23

Kuliešis A, Kulbokas G, Kasperavičius A, Kuliešis AA (2014) Validation of generalized height-diameter model based on Lithuanian NFI data. Balt For 20:287-300

Kuliešis A, Kasperavičius A, Kulbokas G (2016) National resource availability reports. Chapter 28 Lithuania. In:Vidal C, Alberdi I, Hernandez L, Redmond J (ed) National Forest Inventories Assessment of Wood Availability and Use. Springer, accepted

Loetsch F, Zöhrer F, Haller KE (1973) Forest inventory. Volume II. BLV Verlagsgesellschaft mbH, München, 472 p. ISBN 3-405-10812-8

Montenegro Ministry of Agriculture and Rural Development (2008) National Forest Policy of Montenegro, Podgorica

Montenegro Ministry of Agriculture and Rural Development (2013). The first National Forest Inventory of Montenegro. Final report, Podgorica

Pretzsch H (2010) Forest dynamics, growth and yield. Springer-Verlag, Berlin Heidelberg doi:10.1007/978-3-540-88307-4

Šmelko Š, Šeben V, Bosela M, Merganič J, Jankovič J (2008) National forest inventory and monitoring of the Slovak Republik 2005-2006. National Forest Centre - Forest Research Institute, Zvolen 
Stevenson DD, Meyer HA (1940) An application of the continuous inventory system of management. J For 38:347-349

Stott CB, Ryan EJ (1939) A permanent sample plot technique adapted to commercial timber stands. J For 37:347-349

Talarczyk A (2014) National forest inventory in Poland. Balt For 20:333340

Tomppo E, Gschwantner T, Lawrence M, McRoberts RE (eds) (2010) National forest inventories. Pathways for common reporting. Springer Science + Business Media BV, London, New York. doi: 10.1007/978-90-481-3273-1
Tomter SM, Kuliešis A, Gschwantner T (2016) Annual volume increment of the European forests - Description and evaluation of the national methods used. Annals of Forest Science; accepted

ÚHÚL (2007) National Forest Inventory in the Czech Republic 20012004: 469 Introduction, Methods, Results. ÚHÚL, Brandýs nad Labem

UNECE/FAO (2000) Forest resources of Europe, CIS, North America, Australia, Japan and New Zealand. Global forest resources assessment 2000. Main report. Geneva timber and forest study papers, No. 17. United Nations, New York and Geneva, $445 \mathrm{p}$ 